\title{
Integration of SWOT Analysis with Remote Sensing Method as a Sustainable Planning and Management tool for Protected Areas
}

\author{
Murat Atasoy, 1,a, \\ ${ }^{1}$ Department of Interior Architecture and Environmental Design, Faculty of Architecture, Design, and Fine Arts, Osmaniye Korkut Ata \\ University, 80000 Osmaniye, Turkey \\ *Corresponding author
}

A R T I C LE I N F O A B S T R A C T

Research Article

Protected areas are one the most important nature conservation landscapes and during the last few decades, the importance of natural areas have been considered as a priority for lifestyle preferences of people around the world. Karatepe Aslantas National Park is one of the examples for these protected areas in Turkey, however; there have been limited studies focusing on the preservation and development of a socioeconomic plan for the aforementioned national park. Therefore, this study aims to develop planning and management priorities of Karatepe Aslantaş National Park and determine tourism potential towards future-oriented conservation. In this regard, a SWOT analysis was performed to develop sustainable planning and design proposals. To determine the historical transformation of a protected area and its surroundings, Land use/land cover-change (LUCC)

Keywords:

Change detection

Ecological planning

Karatepe Aslantaş National Park

Protected areas

Remote sensing detection was performed using Landsat 7 ETM and Landsat TIRS/OLI satellites images of the study area for the years 1990 and 2018. The results showed that in 1990, the mixed forest class dominated the study area (2376.6 ha), likewise, it was the most effective land cover class in 2018 (2178.14 ha). Agricultural land with natural vegetation class occupied the second largest area for both 1990 and 2018 with 1264.72 ha and 880.13 ha, respectively. A marked decrease was found for the transitional woodland/shrubs cover (565.8 ha in 1990 to 330.35 ha in 2018). Among the all land use classes, the highest percentage of change was found for broad-leaved forest cover at 200\% between 1990 and 2018, while the lowest percentage of change occurred to water bodies with $8.82 \%$ in the same time frame. Regarding the findings, management proposals have been developed to conserve the protected area considering its tourism potential and archeological heritage values. Therefore, it is recommended that the lack of planning and management strategies needs to be fulfilled as a legal commitment by government agencies.

muratatasoy@osmaniye.edu.tr@iDttps://orcid.org/0000-0003-0987-521X

\section{Introduction}

During the last few decades, the importance of natural areas has been considered as a priority for lifestyle preferences of people around the world. Increases in manufacturing, land degradation, natural resource contamination, and urban expansion have resulted in environmental and social problems. More importantly, public demand for recreation areas has gained momentum due to population increase in cities, yet natural and financial resources of recreational activities are limited. To minimize the negative consequences of these social and environmental issues, governments declared urgent and intense attempts to conserve the green spaces and associated natural sources by organizing social and economic conventions (Doğanay et al., 2009; Eker and Demircioğlu, 2016; Rezazadeh et al., 2017; Atasoy, 2018).
Protected areas are one of these natural conservation landscapes and they are defined as areas consented and devoted to derive long term achievements of protecting nature sustainably (Lewis et al., 2019). According to the most recent report of World Database on Protected Areas (WDPA), there are currently 242,423 designated protected areas around the world and the coverage of both marine and terrestrial protected areas have improved and achieved a remarkable process with $17.7 \%$ and $15 \%$, respectively (WDPA, 2019). The expansion of protected areas has occurred especially in developing countries worldwide due to high levels of biodiversity and an increase in open green spaces and natural reserves of these countries (NaughtonTreves et al., 2005). According to WDPA, the largest percent rises of protected areas were observed in Mexico, 
Central America, and the Caribbean at $10.38 \%$ and in the European side of the Mediterranean region at $10.28 \%$. Nevertheless, inappropriate management of protected areas and malpractices has transformed these landscapes into understaffed, insufficiently funded, and degraded natural areas (Le Saout et al., 2013) (Figure 1).

Tourism researches focusing on protected areas and their health use sustainability as the key factor of management and planning approach. Since tourism has been widely considered as one of the primary sectors pioneering economic development of countries, the historical, ecological, scientific, and aesthetic values of protected areas are increasing at an exponential rate (Hayes, 2006). Also, historical environments can facilitate a strong connection between public and nature which therefore leads to appreciating historical and archaeological heritage. Given that government-mandated designation of conservation is required for environmental sustainability, the main question is whether national park policies and management plans are adequately implemented in order to protect national biodiversity and the public is included in the decision-making process (Hayes, 2006; Cengiz, 2007; Nordh and Østby, 2013).

Turkey is a developing country that has a territory consists of an enriched ecosystems and habitat diversity with several protected areas. Karatepe Aslantaş National Park is one of the examples for these protected areas in Turkey, however; there have been limited studies focusing on the preservation and development of the socioeconomic plans for the aforementioned national park. Therefore, this study aims to develop planning and management priorities of Karatepe Aslantaş National Park and determine tourism potential towards future-oriented conservation.

\section{Material and Methods}

This study was carried out in Karatepe Aslantaş National Park located in Osmaniye Province of Turkey on the foothills of the Taurus Mountains (Figure 2). The altitude of the park is between 65 and 538 meters above sea level. The park was established in September 1958 as the country's first open-air museum and second protected area in this class covering 4,715.00 ha on a peninsula of the Aslantas Dam. The park is also known as an archeological park as the late Hittite citadel including a path encompassing two gateways inside the citadel and the lake on the Ceyhan River (Figure 3) (Eker and Demircioğlu, 2016).

The flora of Karatepe Aslantaş National Park inhabits various endemic plant species including Glycyrrhiza flavescens, Anthemis arenicola var. arenicola, Rigonella raphina, Scorzonera lacera. Other taxons of plant species in the park can be listed as: Platanus orientalis, Ostrya carpinifolia, Celtis australis, Nerium oleander, Vitex agnus-castus, Rubus sanctus, Clematis cirrhosa, Ampelopsis orientale, Ceterach officinarum, Parietaria judaica, Umbilicus horizontalis, Valerianella dentata, Cyclamen pseudo-ibericum, Cyclamen pseudoibericum, Ricotia sinuata, Symphytum aintabicum, and Alkanna kotschyana.The fauna of the national park consists of 185 types of bird species among which 120 of them are listed in the IUCN Red List of Threatened Species (DKMP, 2019).
In order to derive information of the landscape planning proposal for the national park and ancient citadel, interviews with local people were conducted. Then, a SWOT (strengths, weaknesses, opportunities, threats) analysis of the protected area was undertaken to develop sustainable planning and design proposals for the study area. The SWOT analysis was firstly used for business management in the late 1970s, then applied in different fields such as ecological researches as a tool of analysis and planning for various areas (Baz et al., 2009).

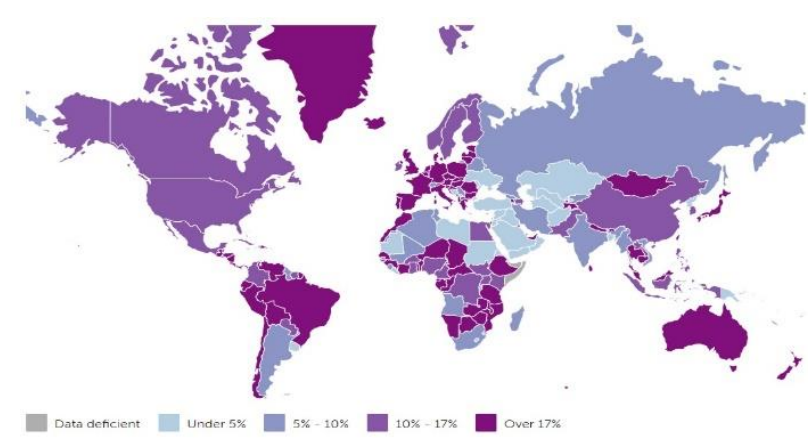

Figure 1. The global extent of terrestrial protected area coverage between countries (WDPA 2019).

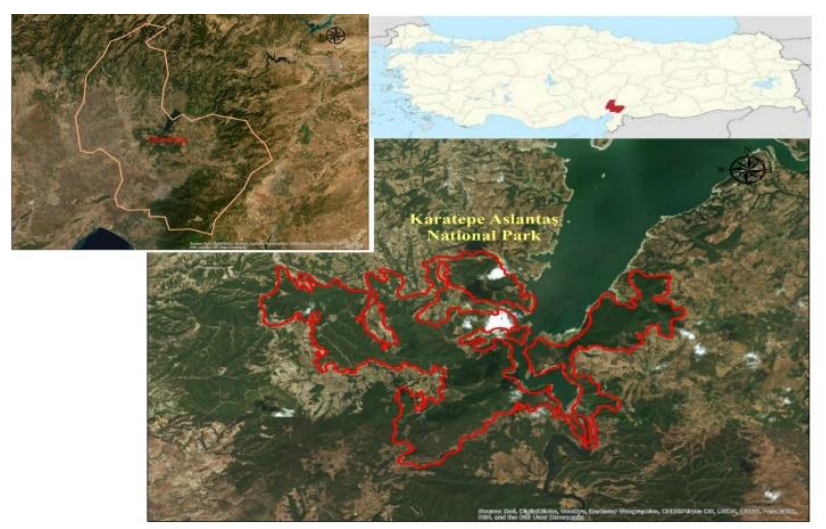

Figure 2. Geographic location and digitized map of Karatepe Aslantaş National Park

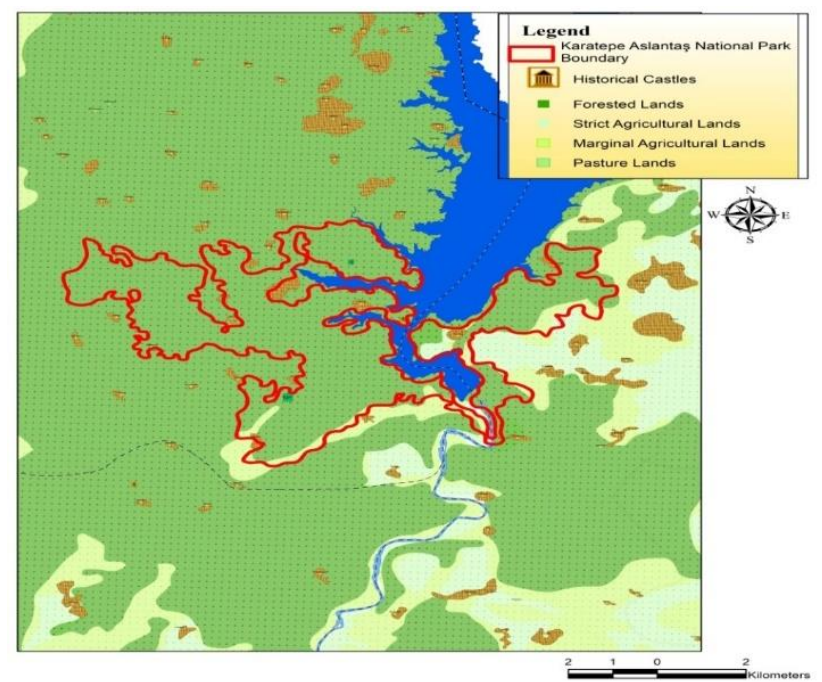

Figure 3. Environment plan of the Karatepe Aslantaş National Park. 
To determine the historical transformation of the protected area and its surroundings, a change detection method derived from Kintz et al. (2006) was applied. Land use/land cover change (LUCC) detection was performed using Landsat 7 ETM and Landsat TIRS/OLI satellites images of the study area for the years 1990 as the oldest and 2018 as the most recently available period. The LUCC data was derived from CORINE Land Cover (CLC) database on November 11, 2019. The land cover classification and nomenclature consist of five major groups as artificial surfaces, agricultural areas, forests and semi-natural areas, wetlands, and water bodies with 44 land use classes (CLC, 2019). For the present study, several 8 out of 44 classes in the CLC nomenclature were identified and overlapped within the boundaries of the Aslantaş National Park using ArcGIS 10.3 Software. After that, the change detection analysis is applied to the coverage area of each class within the boundary of the study area.

\section{Results}

The results of the SWOT analysis were shown in Table 1. The Karatepe Aslantaş National Park has an important potential for tourism and recreation activities due to its natural and cultural values. The park is also rich in consideration of establishing ecotourism strategy and management plan. The ecotourism activities of the park consist of bird watching, trekking, adventure tourism, cultural and historical tours, wildlife observations, picnic activities, cycling, and camping.

Regarding the geospatial analyses conducted, the LUCC maps for the time frame from 1990 to 2018 are provided in Figure 4. Based on the LUCC maps, the change detection results of the Karatepe Aslantaş National Park are also shown in Table 2. In 1990, the mixed forest class dominated the study area (2376,6 ha), likewise, it was the most effective land cover class in 2018 (2178,14 ha). Agricultural land with natural vegetation class occupied the second largest area for both 1990 and 2018 with 1264,72 ha and 880,13 ha, respectively. A marked decrease was found for the Transitional woodland/shrubs cover (565,8 ha in 1990 to 330,35 ha in 2018). Coniferous forestcovered 435,13 ha in 1990 and 813,56 ha in 2018, and complex cultivation pattern occupied 112,17 ha in 1990 and 78,89 ha in 2018. Complex cultivation land class covered 112,17 ha in 1990 , whereas it occupied 78,89 ha in 2018. Water bodies, permanently irrigated land, and broad-leaved forest classes covered 83,85 ha, 38,21 ha, and 36,98 ha, respectively in 1990 , while they occupied 91,25 ha, 33,28 ha, and 110,94 ha in 2018, subsequently. There was not any urban land use and industrial area class detected within the study area. Among the all land use classes, the highest percentage of change was found for broad-leaved forest cover at $200 \%$ between 1990 and 2018 , while the lowest percentage of change occurred to water bodies with $8,82 \%$ in the same time frame (Table 2 ).

Table 1. The SWOT analysis of the Karatepe Aslantaş National Park and its adjacent area

\begin{tabular}{|c|c|}
\hline Strengths & Weaknesses \\
\hline $\begin{array}{l}\text { - } \\
\text { - } \quad \text { Preserved area with original archeological relics and } \\
\text { inscriptions } \\
\text { - } \quad \text { Easy access to the entrance of park and museum } \\
\text { - The first open-air museum of the country } \\
\text { - } \quad \text { Richness of vegetation with endemic plants and } \\
\text { biological variation in fauna } \\
\text { - Water features facilitating a natural reserve for public } \\
\text { Tourism potential aimed at collaboration with local } \\
\text { people }\end{array}$ & $\begin{array}{l}\text { - Underrated historical protected area in spite of } \\
\text { original natural values } \\
\text { - Lack of activities in advertising and marketing } \\
\text { - Insufficient infrastructure and planning } \\
\text { - Inadequate number of visitors due to lack of } \\
\text { information } \\
\text { - Lack of recreational activities } \\
\text { - Inadequate accommodation facilities for tourists }\end{array}$ \\
\hline Opportunities & Threats \\
\hline 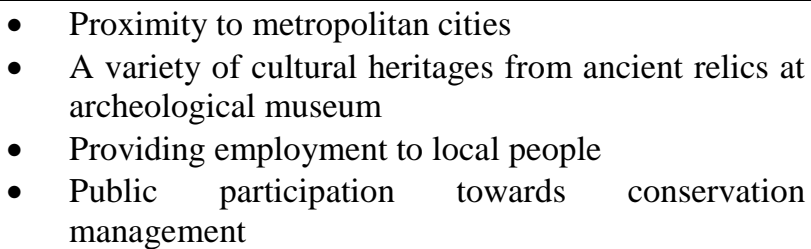 & $\begin{array}{l}\text { - Increasing contamination in Aslantaş Dam due to } \\
\text { heavy traffic in surroundings } \\
\text { - } \quad \text { Proximity to an active earthquake zone } \\
\text { - } \quad \text { Unrestrained logging activities causing loss of plants } \\
\text { - Increase in air pollution leading to decrease in fauna }\end{array}$ \\
\hline
\end{tabular}

Table 2. Area of each LUCC classes with their percentage change between 1990 and 2018

\begin{tabular}{l|cccc}
\multicolumn{1}{c|}{ Land use/land cover classes } & $\begin{array}{c}\text { Land use in } \\
1990(\mathrm{ha})\end{array}$ & $\begin{array}{c}\text { Land use in } \\
2018(\mathrm{ha})\end{array}$ & $\begin{array}{c}\text { Land use change } \\
1990-2018(\mathrm{ha})\end{array}$ & $\begin{array}{c}\text { Land use change } \\
1990-2018(\%)\end{array}$ \\
\hline Broad-leaved forest & 36.98 & 110.94 & 73.96 & 200.00 \\
Coniferous forest & 435.13 & 813.56 & 378.43 & 86.96 \\
Transitional woodland/shrubs & 565.8 & 330.35 & -235.45 & -41.61 \\
Agricultural land with natural vegetation & 1264.72 & 880.13 & -384.59 & -30.4 \\
Complex cultivation pattern & 112.17 & 78.89 & 33.28 & 29.66 \\
Permanently irrigated land & 38.21 & 33.28 & -4.93 & -12.9 \\
Mixed forest & 2178.14 & 2376.6 & 198.46 & 9.11 \\
Water bodies & 83.85 & 91.25 & 7.4 & 8.82 \\
\hline
\end{tabular}




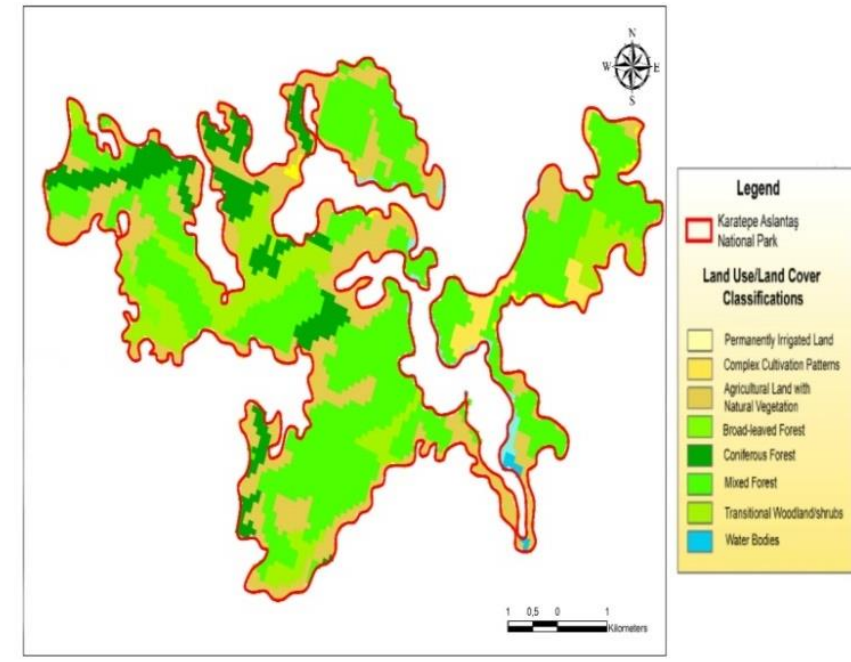

Land Use/Land Cover in 1990

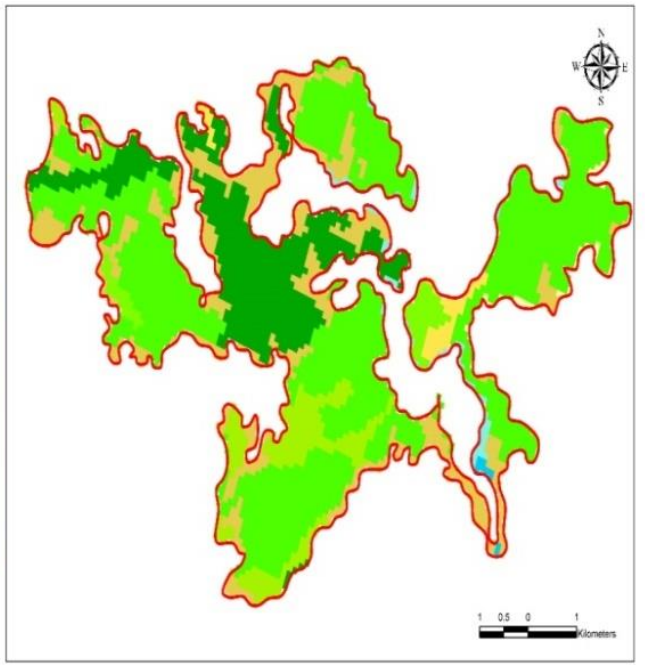

Land Use/Land Cover in 2018

Figure 4. LUCC maps of the Karatepe Aslantaş National Park for 1990 and 2018.

\section{Discussion and Recommendations}

Although SWOT analysis is widely applied for determining the management policies and tourism potential of protected areas, this study is the first application for the current management condition of the Aslantaş National Park and to provide the best fit conservation strategy applying SWOT and remote sensing analyses. SWOT analysis and remote sensing methods such as LUCC change detection and map digitizing are often used to determine the tourism potential of protected areas as cost-friendly and time-efficient tools (NaughtonTreves et al., 2005; Cengiz, 2007; Scollozzi et al., 2014). Thus, SWOT analysis and remote sensing techniques can coordinately provide a sustainable management plan by discussing multiple aspects through the conservation of natural protected areas.

According to the results of the LUCC change detection analysis shown in Table 2, there was a significant increase found for broad-leaved forest cover in the study time frame. Also, the coniferous forest cover has expanded as the second largest land use class of the study area. Based on these findings, the vegetative cover of the protected area has been conserved against deforestation and illegal logging activities. Furthermore, the decrease detected in transitional woodland/shrubs cover shows that bushy and herbaceous vegetation with scattered trees could have regenerated to new natural afforestation activity for the study area. Although it was found by the SWOT analysis that Karatepe Aslantaş National Park is an underrated historical protected area despite its original natural vegetative cover, the LUCC change detection results indicate the natural forest regeneration has improved, yet in danger due to the threat of illegal logging activities. Therefore, it is recommended that a lack of planning and management strategies to conserve the flora and fauna in the study area needs to be fulfilled as a legal commitment by government agencies.

On the contrary to the forest cover land use classes, agricultural land with natural vegetation cover class had a significant decrease in the protected area during the present study period (Table 2, Figure 4). Considering the surroundings of the study area, local inhabitants often benefit from agricultural activities, yet there is not sufficient interaction between government organizations and the local community regarding the decrease of agricultural land with natural land cover. Also, a decrease in agricultural land with natural vegetation cover can lead to deterioration of biological diversity and water quality in the study area. Therefore, the results of this study can help to raise awareness of the planning and management efforts for the protected area. There have been several studies (Güngör and Arslan 2004; Cengiz 2007; Demir et al. 2016; Çeşmeci and Tekeli 2018; Atasoy 2019) investigating the relationship between tourism potential of protected areas and open green spaces in Turkey, however; the present study contributes to the literature by integrating a quantitative approaching to develop a sustainable management strategy for Karatepe Aslantaş National Park. Therefore, examples of management proposals have been developed to conserve the protected area considering its tourism potential and archeological heritage values.

- The road of the national park is accessible for the visitors, yet the infrastructure is not sufficiently managed which causes surface run-off and degradation of paving materials. To eliminate this issue, the roadside of the main road can be planted with species reducing erosion and increasing air quality.

- The parking spaces are not user-friendly and there should be more parking spaces for the visitors.

- The archeological citadel and relics are open to visitors in the open-air museum, yet cleaning and maintenance are not sufficient to sustain the archeological heritage in the protected area.

- The walking trail facilitates visitors to access the recreational areas in the park. However, there is not any guidance to help visitors observe the scenic beauty of flora and fauna of the protected area.

- A map of the national park which includes signs of facilities and archeological relics can be designed so that guests can find the appropriate route surrounding the entire area. 
- The lighting of the national park requires to be improved to create a safe and convenient walking pathway for visitors and local people residing surroundings of the area.

- A souvenir shop can be designed adjacent to the ticket office so that visitors can purchase gifts and some local products such as Karatepe hand-woven rugs. Thus, the local economy can improve and contribute to the regional economic income of local people.

- The government can plan and build an exhibition center in the protected area where historical and archeological values of the national park and relics are displayed to domestic and international visitors. In this way, the advertisement of the open-air museum and national park will increase the popularity of the natural structure in the region.

\section{Acknowledgement}

The author wishes to thank anonymous reviewers for their constructive comments. The author also acknowledges the residents of the Karatepe Aslantaş National Park for their help and support.

\section{References}

Atasoy M. 2018. Monitoring the urban green spaces and landscape fragmentation using remote sensing: a case study in Osmaniye, Turkey. Environmental Monitoring and Assessment, 190(12): 713. DOI: $10.1007 / \mathrm{s} 10661-018-7109-1$

Atasoy M. 2019. Assessing the impacts of land-use/land-cover change on the development of urban heat island effects. Environment, Development and Sustainability, 1-11. DOI: 10.1007/s10668-019-00535-w.

Baz I, Geymen A, Er SN. 2009. Development and application of GIS-based analysis/synthesis modeling techniques for urban planning of Istanbul Metropolitan Area. Advances in Engineering Software, 40(2): 128-140.

Cengiz T. 2007. Tourism, an ecological approach in protected areas: Karagöl-Sahara National Park, Turkey. The International Journal of Sustainable Development \& World Ecology, 14(3): 260-267.

CLC. 2019. Copernicus Land Monitoring Service. Available from: https://land.copernicus.eu/pan-european/corine-landcover [Accessed: 10.12.2019].

Çeşmeci N, Tekeli EK. 2018. Göreme Tarihi Milli Parkı'nın sürdürülebilir turizm açısından değerlendirilmesi. TURAN Center for Strategic Researches, 10(40): 148.

Demir S, Esbah H, Akgün AA. 2016. Quantitative SWOT analysis for prioritizing ecotourism-planning decisions in protected areas: Igneada case. International Journal of Sustainable Development \& World Ecology, 23(5): 456-468.
DKMP. 2019. General Directorate of Natural Conservation and National Parks. Available from: https://www.tarimorman.gov.tr /DKMP/Sayfalar/EN/AnaSayfa.aspx [Accessed:15.12.2019].

Doğanay S, Alım M, Altaş NT. 2009. A Sample for the environmental protection implementation in Turkey: National Parks. 1st International Symposium on Sustainable Development, Sarajevo, June 9-10, International Burch University, 223-230.

Eker Ö, Demircioğlu H. 2016. An application of travel-cost method and willingness to pay surveys for Karatepe Aslantaş National Park in Turkey. 1st International Mediterranean Science and Engineering Congress, Çukurova University, Adana, Turkey, October 26-28, Çukurova University, 13161321.

Güngör S, Arslan M. 2004. Turizm ve rekreasyon stratejileri için SWOT analizi, görsel kalite değerlendirmesi, turizm tesislerinin beğenilirliği ve turizm tesisleri durum analizi uygulaması; Beysehir İlçesi örneği. SÜ Ziraat Fakültesi Dergisi, 18(33):68-72.

Hayes TM. 2006. Parks, people, and forest protection: an institutional assessment of the effectiveness of protected areas. World Development, 34(12): 2064-2075.

Kintz DB, Young KR, Crews-Meyer KA. 2006. Implications of land use/land cover change in the buffer zone of a national park in the tropical Andes. Environmental Management, 38(2): 238-252.

Le Saout S, Hoffmann M, Shi Y, Hughes A, Bernard C, Brooks TM, Bertzky B, Butchart SH, Stuart SN, Badman T, Rodrigues AS. 2013. Protected areas and effective biodiversity conservation. Science, 342(6160): 803-805.

Lewis E, MacSharry B, Juffe-Bignoli D, Harris N, Burrows G, Kingston N, Burgess ND. 2019. Dynamics in the global protected-area estate since 2004. Conservation Biology, 33(3): 570-579.

Naughton-Treves L, Holland MB, Brandon K. 2005. The role of protected areas in conserving biodiversity and sustaining local livelihoods. Annual Review of Environment and Resources, 30: 219-252.

Nordh H, Østby K, 2013. Pocket parks for people-A study of park design and use. Urban Forestry \& Urban Greening, 12(1): 1217.

Rezazadeh S, Jahani A, Makhdoum M, Meigooni HG. 2017. Evaluation of the strategic factors of the management of protected areas using SWOT Analysis-Case study: Bashgol Protected Area-Qazvin Province. Open Journal of Ecology, 7(1): 55-68.

Scolozzi R, Schirpke U, Morri E, D'Amato D, Santolini R. 2014. Ecosystem services-based SWOT analysis of protected areas for conservation strategies. Journal of Environmental Management, 146: 543-551.

WDPA. 2019. World Database on Protected Areas, Protected Planet Live Report 2020. UNEP-WCMC, IUCN and NGS: Cambridge UK; Gland, Switzerland; and Washington, D.C., USA, ISBN: 978-92-807-3721-9. 